\title{
A case of Hodgkin's lymphoma with severely impaired liver function treated successfully with gemcitabine followed by ABVD
}

This article was published in the following Dove Press journal:

Journal of Blood Medicine

23 March 2015

Number of times this article has been viewed

\author{
Rajshekhar Chakraborty' \\ Shiva Kumar Reddy \\ Mukkamalla ${ }^{2}$ \\ Garfield Gutzmore ${ }^{2}$ \\ Hon Cheung Chan ${ }^{2}$ \\ 'Hospitalist Services, Essentia Health, \\ Brainerd, MN, USA; '2Department of \\ Internal Medicine, Queens Hospital \\ Center (Affiliated Icahn School of \\ Medicine at Mount Sinai), Jamaica, \\ NY, USA
}

\begin{abstract}
Hodgkin's lymphoma (HL) originates from clonal B cells and is the most common malignancy in the second decade of life. Liver involvement is uncommon at presentation in patients with $\mathrm{HL}$ and there is a paucity of data for treatment of patients with severely impaired liver function. We present an unusual case of HL with severe hepatic impairment, splenomegaly and multiple chromosomal abnormalities that was treated initially with gemcitabine and steroids. Once liver function tests improved, six cycles of Adriamycin, bleomycin, vinblastine, and dacarbazine were administered. The patient remains in remission at 3.5 years of follow-up.

Keywords: hepatomegaly, cytogenetics, remission
\end{abstract}

\section{Case report}

A 27-year-old Hispanic man was admitted to the Queens Hospital Center because of cough, weakness, night sweats, and weight loss.

The patient was well until 1 month before admission when he started having weakness, coughing, and sweats. He had traveled to Puerto Rico 1 month prior to admission. On return to the United States he saw a physician for the above symptoms and was prescribed azithromycin for 5 days. However, the symptoms progressively worsened over weeks and at presentation also included drenching night sweats and dizziness. His coworkers noted him to be paler. On interview, he was noted to have lost 25 pounds over 4 to 6 weeks. He denied any fever, chills, and rigors. He had fatigue, and felt early satiety due to pressure in the left upper quadrant of abdomen. He denied any travel to the countryside, significant outdoor activities, hiking or spelunking. He also denied any bright red blood per rectum, melena, myalgia, arthralgia, hematuria or dark colored urine.

The patient had no prior medical or surgical history. He denied taking any medications. He was a non-smoker, drank socially, and did not take any illicit or recreational drugs. His father was recently diagnosed with multiple myeloma and his mother had diabetes mellitus.

On physical examination, the patient was alert and oriented. The blood pressure was $119 / 76 \mathrm{mmHg}$, the temperature $100.0^{\circ} \mathrm{F}$, the pulse $119 / \mathrm{min}$ with regular rhythm, the respiratory rate $16 / \mathrm{min}$ with oxygen saturation $100 \%$ on ambient air. The patient had pale conjunctiva, icteric sclera, non-tender left supraclavicular and cervical lymphadenopathy, hepatomegaly with palpable liver edge $2-3 \mathrm{~cm}$ below right costal margin and splenomegaly.

On hospital day (HD) 1, his complete blood count showed white blood cell count 3,100/mcL, hemoglobin $6.6 \mathrm{~g} / \mathrm{dL}$, hematocrit $20 \%$ and platelets $76,000 / \mathrm{mcL}$.
Correspondence: Rajshekhar

Chakraborty

Essentia Health-Brainerd, 523,

N 3rd street, Brainerd, MN 5640I, USA

$\mathrm{Tel}+\mathrm{I} 3476086329$

Fax +17188836124

Email rajshekhar.ucms@gmail.com
Journal of Blood Medicine 2015:6 93-97 (c) (i) (9) 2015 Chakraborty et al. This work is published by Dove Medical Press Limited, and licensed under Creative Commons Attribution - Non Commercial (unported, v3.0) License. The full terms of the License are available at http://creativecommons.org/licenses/by-nc/3.0/. Non-commercial uses of the work are permitted without any further penw so how to request permission may be found at: http://www.dovepress.com/permissions.php 
Liver function tests (LFTs) were abnormal with alkaline phosphatase of $611 \mathrm{u} / \mathrm{L}$, aspartate aminotransferase (AST) of $42 \mathrm{u} / \mathrm{L}$, gamma glutamyl transpeptidase (GGT) of $68 \mathrm{u} / \mathrm{L}$, lactate dehydrogenase $(\mathrm{LDH})$ of $581 \mathrm{u} / \mathrm{L}$, total bilirubin of $2.67 \mathrm{mg} / \mathrm{dL}$ and conjugated bilirubin of $1.25 \mathrm{mg} / \mathrm{dL}$. Anemia workup revealed a reticulocyte count of $1,231 / \mu \mathrm{L}$ with reticulocytes $5.53 \%(0.5 \%-1.5 \%)$, iron $60 \mu \mathrm{g} / \mathrm{dL}(60-160 \mu \mathrm{g} / \mathrm{dL})$, total iron binding capacity (TIBC) of $213 \mu \mathrm{g} / \mathrm{dL}(250-460 \mu \mathrm{g} / \mathrm{dL})$, ferritin of 3,128 ng/mL (15-200 ng/mL), vitamin B12 level of $1,387 \mathrm{pg} / \mathrm{mL}(200-900 \mathrm{pg} / \mathrm{mL})$ and serum folate $11.25 \mathrm{ng} / \mathrm{mL}$ (2.5-20 ng/mL).

Initial review of a peripheral blood smear showed thrombocytopenia with occasional large platelets, poikilocytosis, polychromasia, decreased white blood cells without toxic granulation and no schistocytes. Tests for hemolysis, including direct anti-globulin test and haptoglobin level, were negative on HD 2.

A computed tomography (CT) scan of chest, abdomen, and pelvis done on HD 1 revealed enlarged lymph nodes in the mediastinum, retroperitoneum and splenomegaly and hepatomegaly.

A workup for infectious etiologies was performed as summarized in Table 1. Testing for human immunodeficiency virus was negative. A bone marrow biopsy was performed on HD 4. A lymph node biopsy was requested, given pancytopenia and concurrent lymphadenopathy and performed on HD 6.

\section{Initial diagnostic results}

The bone marrow biopsy showed a markedly hypercellular marrow (90\%-100\%) with erythroid hyperplasia, left shifted granulocytic series, and increased megakaryocytes with atypical and dysplastic forms, suggesting a myelodysplastic or myeloproliferative disorder. The bone marrow aspirate smears showed occasional abnormal mononuclear cells, likely vacuolated lymphoid precursors and mature myeloid and erythroid lines with no evidence of blasts. The findings were later interpreted as an unusual reaction to Hodgkin's lymphoma (HL).

Cytogenetic analysis of a bone marrow specimen revealed tetraploidy, aneuploidy, and multiple abnormalities including XXY, $\operatorname{add}(2)(\mathrm{p} 25), \operatorname{add}(5)(\mathrm{p} 15) \times 2, \operatorname{add}(6)(\mathrm{q} 27), \operatorname{add}(10)(\mathrm{q} 23)$, $\operatorname{add}(13)(\mathrm{p} 11), \operatorname{add}(14), \operatorname{del}(10)(\mathrm{q} 22, \mathrm{q} 23),+5,+8$ and +9 .

\section{Patient outcome and initial hospital course}

The patient was initially treated with supportive transfusions while a diagnosis was being established. The liver enzymes including total and direct bilirubin worsened while awaiting results from the biopsies. Total bilirubin reached $9.22 \mathrm{mg} / \mathrm{dL}$ by HD 14 (Table 2).

Table I Laboratory data (infectious and autoimmune workup)

\begin{tabular}{llll}
\hline Variable & Reference range & Value & Interpretation \\
\hline Hepatitis B surface Ab & & Reactive & Positive \\
Hepatitis B surface Ag & & Non-reactive & Negative \\
Hepatitis B core Ab & & Non-reactive & Negative \\
Hepatitis C Ab & $<0.9 \mid$ & Non-reactive & Negative \\
CMV Ab (IgM) & $<0.9 \mid$ & 0.39 & Negative \\
EBV capsid Ab IgG & $<0.9 \mid$ & $1.4 \mid$ & Positive \\
EBV capsid Ab IgM & $<0.9 \mid$ & 0.00 & Negative \\
EBNA Ab IgG & $<0.9$ & 4.10 & Positive \\
CMV Ab (IgG) & $<0.9$ & 1.12 & Positive \\
Parvovirus BI9 Ab (IgG) & $<0.9$ & 4.1 & Positive \\
Parvovirus BI9 Ab (IgM) & & 0.3 & Negative \\
Mono heterophile Ab & $16-200 \mathrm{mg} / \mathrm{dL}$ & Negative & Negative \\
Haptoglobin & & 203 & Elevated \\
Urine histoplasma Ag & & Negative \\
Serum histoplasma Ab & & & Negative \\
JAK 2 mutation & $<48$ copies $/ \mathrm{mL}$ & & Negative \\
HIV-I RNA, quantitative & $<0.9$ & $<48$ copies $/ \mathrm{mL}$ & Negative \\
Dengue IgG Ab & $<0.9$ & 0.23 & Negative \\
Dengue IgM Ab & & 0.24 & Negative \\
Syphilis IgG & $<1: 20$ & Negative & 2 \\
ANA & & Negative & Negative \\
Anti-SM Ab & $<200$ copies $/ \mathrm{mL}$ & Negative & 2 \\
Anti-mitochondrial Ab & $<200$ copies $/ \mathrm{mL}$ & Negative \\
CMV DNA quantitative & & Positive
\end{tabular}

Abbreviations: ANA, anti-nuclear antibody; Anti-SM, anti-smith antibody; CMV, cytomegalovirus; EBNA, Epstein-Barr nuclear antigen; EBV, Epstein-Barr virus. 
Table 2 Laboratory data

\begin{tabular}{|c|c|c|c|c|c|c|c|c|c|c|}
\hline \multirow[t]{2}{*}{ Variable } & \multirow{2}{*}{$\begin{array}{l}\text { Reference } \\
\text { range }\end{array}$} & \multicolumn{9}{|c|}{ Hospital Day (D) } \\
\hline & & D I & D 10 & D I 2 & D 20 & D 30 & D 33 & 2 months & 6 months & 2 years \\
\hline Hemoglobin (g/dL) & $13.5-17.5$ & 6.6 & 9.3 & 8.6 & 8.7 & 9.4 & 8.9 & 13 & 14.4 & 15.7 \\
\hline Hematocrit (\%) & $4 I-53$ & 20 & 26.9 & 25.1 & 25.3 & 27.3 & 25.8 & 38.2 & 43.1 & 46.5 \\
\hline White cell count $\left(\mathrm{k} / \mathrm{mm}^{3}\right)$ & $4.5-11$ & 3.1 & 1.7 & 1.6 & 1.9 & 3.5 & 3.4 & 4.1 & 2.9 & 8.2 \\
\hline Neutrophils (\%) & $40-70$ & 58.3 & 60.1 & 63 & 72.2 & 70.1 & 59.6 & 48.9 & 21.4 & 69.7 \\
\hline Lymphocytes (\%) & $22.2-43.6$ & 19.9 & 19.7 & 19.5 & 17.8 & 25.7 & 36.8 & 47.7 & 63.7 & 22.7 \\
\hline Monocytes (\%) & $2-11$ & 21.2 & 19.9 & 17.5 & 9.8 & 3.7 & 3.2 & 1.5 & 13.3 & 5.6 \\
\hline Eosinophils (\%) & $0-7.5$ & 0.4 & 0.5 & 0.0 & 0.1 & 0.2 & 0.3 & 0.2 & 1.6 & 0.3 \\
\hline Basophils (\%) & $0-2$ & 0.2 & 0.1 & 0.0 & 0.1 & 0.3 & 0.1 & $\mathrm{I} .7$ & 0 & 1.7 \\
\hline Platelets $\left(\mathrm{k} / \mathrm{mm}^{3}\right)$ & $130-400$ & 76 & 57 & 38 & 41 & 10 & 52 & 223 & 247 & 175 \\
\hline Alkaline phosphatase (u/L) & $30-115$ & 611 & 546 & 666 & 821 & 597 & 597 & 107 & 77 & 74 \\
\hline Aspartate aminotransferase (u/L) & $5-40$ & 42 & 75 & 107 & 106 & 34 & 34 & 27 & 30 & 22 \\
\hline Alanine aminotransferase (u/L) & $5-50$ & 28 & 37 & 60 & 190 & 125 & 125 & 42 & 41 & 25 \\
\hline Gamma glutamyl transpeptidase (u/L) & $3-40$ & 68 & 126 & 128 & 253 & 178 & 178 & 122 & 122 & 27 \\
\hline Lactate dehydrogenase (u/L) & $90-225$ & 581 & 510 & 553 & 412 & 125 & 125 & 149 & 126 & $|4|$ \\
\hline Albumin (g/dL) & $3.5-5$ & 2.2 & 1.7 & 1.5 & 1.5 & 2.7 & 2.7 & 4.2 & 4.4 & 4.4 \\
\hline Total bilirubin (mg/dL) & $0-1.5$ & 2.67 & 2.62 & 5.39 & 9.22 & 2.39 & 2.39 & 1.02 & 0.66 & 0.63 \\
\hline Conjugated bilirubin (mg/dL) & $0-0.3$ & 1.25 & $|.5|$ & 3.64 & 5.76 & 1.05 & 1.05 & 0.20 & 0.05 & 0.15 \\
\hline Serum creatinine $(\mathrm{mg} / \mathrm{dL})$ & $0.4-1.6$ & 0.9 & 0.8 & 0.8 & 0.8 & 0.5 & 0.5 & 0.5 & 0.8 & 0.9 \\
\hline
\end{tabular}

A workup for causes of increased LFTs had been initiated on HD 1. A magnetic resonance cholangiopancreatography did not show any intra or extra hepatic biliary obstruction or any clear involvement of the liver by lymphoma, but it identified multiple hypodensities in the spleen. A hepatobiliary iminodiacetic acid scan showed marked hepatomegaly with smooth contour, but no evidence of focal defects.

Drug-induced hepatitis was considered as the patient had been on fluconazole and acetaminophen during the course of his hospital stay. LFTs showed a predominantly obstructive pattern initially and the serum acetaminophen level at presentation was less than $10 \mu \mathrm{g} / \mathrm{mL}$. Workup was done to rule out autoimmune disorders (Table 1).

Prednisone was started on HD 14 in an attempt to stop further decline in LFTs. Despite steroids, his total bilirubin on HD 20 had increased up to $9.22 \mathrm{mg} / \mathrm{dL}$ with conjugated bilirubin of $5.76 \mathrm{mg} / \mathrm{dL}$.

\section{Lymph node biopsy}

A left cervical lymph node biopsy revealed mixed cellularity classical HL with multiple Reed Sternberg and Hodgkin cells with immunohistochemical expression of PAX5, CD30 and CD15, background CD3 positive $T$ cells and $C D$ 20-positive residual follicles. The patient clinically appeared to have stage IVB mixed cellularity classical HL.

\section{Definitive treatment and follow-up}

Due to elevated LFTs, major dose reductions or omission of most chemotherapeutic agents would be needed.
Gemcitabine was considered because of its ability to be used even with hepatic impairment and its effectiveness as a salvage regimen. Gemcitabine was administered at a dose of $600 \mathrm{mg} / \mathrm{m}^{2}$. Intravenous methylprednisone was started along with gemcitabine. After first dose of gemcitabine with methylprednisone, total bilirubin, conjugated bilirubin and alkaline phosphatase levels decreased. Ten days after gemcitabine, conjugated bilirubin was $2.73 \mathrm{mg} / \mathrm{dL}$. Patient developed thrombocytopenia with a nadir of $10,000 / \mathrm{mL}$ and was supported with platelet transfusions.

Thirteen days after the administration of gemcitabine, LFTs were still abnormal but improved sufficiently that dose reduced Adriamycin, bleomycin, vinblastine, and dacarbazine (ABVD) could be administered. He subsequently completed six cycles of ABVD.

A follow-up bone marrow biopsy was done after completing six cycles of ABVD, which showed $70 \%$ cellularity with trilineage hematopoiesis, all three cell lines proceeding to maturity and no cytogenetic evidence of an abnormal clone. A repeat CT scan of the chest, abdomen, and pelvis showed decrease in the size of mediastinal, left supraclavicular, abdominal, and pelvic lymph nodes. A follow-up whole body positron emission tomography/CT scan showed no evidence of fluorodeoxy (FDG) avid tumor and decreased splenomegaly.

\section{Discussion}

HL originates from clonotypic B cells. ${ }^{1}$ The standard regimens used in the USA at the time the patient presented were 
ABVD, Stanford V Regimen and, less commonly, dose escalated BEACOPP (bleomycin, etoposide, Adriamycin, cyclophosphamide, vincristine, procarbazine, prednisone). Older regimens such as MOPP (mechlorethamine, vincristine, procarbazine, prednisone) are less effective than ABVD. ${ }^{2,3}$ There is a paucity of data and published case reports for treatment of patients with HL and severely impaired liver function as this patient presented. Case reports have been published using chemotherapy agents for patients with HL presenting with high bilirubin levels. ${ }^{4-6}$

Many of the active agents used in treatment for HL require extensive dose reduction for severe liver impairment (Table 3). Liver involvement is uncommon at presentation in patients with HL, and is exceptionally rare in the absence of splenic involvement. ${ }^{7,8}$ The hepatic involvement could range from hepatic infiltration by lymphoma to biliary obstruction by lymph node masses or infiltration of the common bile duct.9-11 The LFTs in our case revealed a cholestatic picture with high alkaline phosphatase and conjugated hyperbilirubinemia.

Vanishing bile duct syndrome as a cause of jaundice has also been reported to be associated with HL. ${ }^{4,12,13}$ In one case report, bilirubin level normalized after two cycles of MOPP, one cycle of reduced dose $\mathrm{P}(\mathrm{V}) \mathrm{AG}$ (prednisone, vinblastine was excluded due to potential neurotoxicity, doxorubicin and gemcitabine) followed by six cycles of full dose P(V) AG from 5.4 to $0.15 \mathrm{mg} / \mathrm{dL} .{ }^{4}$ However, the treatment course in that case was complicated with prolonged fever, pancytopenia, severe peripheral polyneuropathy and toxic interstitial pneumonitis, requiring intensive care after receiving two cycles of MOPP. A case report of successful use of DHAP (full-dose dexamethasone, high-dose cytarabine, and cisplatin) in a patient with stage IV nodular sclerosis classical HL with severe hepatic dysfunction resulted in significant improvement in the hepatic function after the administration of DHAP regimen as evidenced by the normalization of serum bilirubin from $6.5 \mathrm{mg} / \mathrm{dL}$ to $1.2 \mathrm{mg} / \mathrm{dL} .^{5}$

Gemcitabine has been shown to be effective as a salvage regimen in patients with refractory $\mathrm{HL}$ with a response rate of $39 \%$ with mild drug related toxicities. ${ }^{14}$ Currently, three gemcitabine based regimens, GVD (gemcitabine, vinorelbine and pegylated liposomal doxorubicin), ${ }^{15}$ GDP (gemcitabine, dexamethasone and cisplatin), ${ }^{16}$ and GCD(R) (gemcitabine, carboplatin, dexamethasone, rituximab) ${ }^{17}$ have been evaluated for use in relapsed and/or refractory HL. A retrospective study has shown that gemcitabine combined with vinorelbine or cisplatinum and steroid is an effective treatment option with a manageable toxicity profile in patients with post-transplant progression of HL and in patients eligible for allogeneic or second autologous stem cell transplantation as a pre-transplant option. ${ }^{18}$ Manufacturer drug package insert and Phase I pharmacokinetic trials of gemcitabine in patients with hepatic or renal dysfunction have demonstrated that dose adjustments are not necessary for elevated transaminases nor elevated bilirubin and creatinine levels. ${ }^{19,20}$

Table 3 Manufacturer recommended dose reduction of chemotherapeutic agents used in Hodgkin's lymphoma

\begin{tabular}{|c|c|c|c|}
\hline Drug & Moderate hepatic impairment & Severe hepatic impairment & Renal impairment \\
\hline Doxorubicin & $\begin{array}{l}50 \% \text { dose reduction for bilirubin } \\
1.2-3.0 \mathrm{mg} / \mathrm{dL}^{\prime}\end{array}$ & $\begin{array}{l}\text { 75\% dose reduction for bilirubin } \\
3.1-5.0 \mathrm{mg} / \mathrm{dL}^{\prime}\end{array}$ & No dose adjustment needed \\
\hline Bleomycin & No dose adjustment needed & No dose adjustment needed & $\begin{array}{l}\mathrm{CrCl} 40 \text { to } 50 \mathrm{~mL} / \mathrm{min}(70 \% \text { dose }) ; \mathrm{CrCl} 30 \text { to } \\
40 \mathrm{~mL} / \mathrm{min}(60 \% \text { dose }) ; \mathrm{CrCl} 20 \text { to } 30 \mathrm{~mL} / \mathrm{min} \\
\text { ( } 55 \% \text { dose); } \mathrm{CrCl} 10 \text { to } 20 \text { ( } 45 \% \text { dose); } \mathrm{CrCl} \\
5 \text { to } 10 \mathrm{~mL} / \mathrm{min}(40 \% \text { dose })^{2}\end{array}$ \\
\hline Vinblastine & No dose adjustment needed & $\begin{array}{l}50 \% \text { dose reduction for direct } \\
\text { bilirubin greater than } 3 \mathrm{mg} / \mathrm{dL}^{3}\end{array}$ & No dose adjustment needed \\
\hline Dacarbazine & Precaution recommended & Precaution recommended & Precaution recommended \\
\hline Mechlorethamine & No dose adjustment needed & No dose adjustment needed & No dose adjustment needed \\
\hline Vincristine & No dose adjustment needed & $\begin{array}{l}50 \% \text { dose reduction if direct serum } \\
\text { bilirubin greater than } 3 \mathrm{mg} / \mathrm{dL}^{4}\end{array}$ & No dose adjustment needed \\
\hline Procarbazine & No dose adjustment needed & No dose adjustment needed & No dose adjustment needed \\
\hline Etoposide & $\begin{array}{l}\text { Dose reduction by } 50 \% \text { for } \\
\text { bilirubin } 1.5-3.0 \mathrm{mg} / \mathrm{dL}^{5}\end{array}$ & $\begin{array}{l}\text { Not recommended for bilirubin } \\
\text { greater than } 3.0 \mathrm{mg} / \mathrm{dL}^{5}\end{array}$ & $\begin{array}{l}25 \% \text { dose reduction recommended for } \mathrm{CrCl} \\
15-50 \mathrm{~mL} / \mathrm{min}\end{array}$ \\
\hline Methylprednisolone & No dose adjustment needed & No dose adjustment needed & No dose adjustment needed \\
\hline Cytarabine & $\begin{array}{l}\text { Dose may need to be reduced, } \\
\text { exact data not available }\end{array}$ & $\begin{array}{l}\text { Dose may need to be reduced, } \\
\text { exact data not available }\end{array}$ & $\begin{array}{l}\text { Dose may need to be reduced, increased } \\
\text { neurotoxicity associated with } \mathrm{CrCl} \text { less than } \\
60 \mathrm{~mL} / \mathrm{min}\end{array}$ \\
\hline Cisplatin & Data not available & Data not available & $\begin{array}{l}\text { Repeat courses not recommended until } \\
\text { serum creatinine less than } 1.5 \mathrm{mg} / \mathrm{dL} \text { and/or } \\
\text { BUN is less than } 25 \mathrm{mg} / \mathrm{dL}^{6}\end{array}$ \\
\hline Cyclophosphamide & No dose adjustment needed & No dose adjustment needed & No dose adjustment needed \\
\hline
\end{tabular}

Abbreviations: $\mathrm{BUN}$, blood urea nitrogen; $\mathrm{CrCl}$, creatinine clearance rate. 
Finally, chromosomal abnormalities in HL have not been well studied to characterize a coherent cytogenetic picture. ${ }^{21}$ Recent studies have designated some common chromosomal aberrations including gains of short arm of chromosome 2 involving REL oncogene locus ${ }^{1,22}$ and chromosomal breakpoints involving immunoglobulin loci. ${ }^{23}$ Frequent occurrence of abnormalities involving 1p, 1q and 6q chromosomal arms was shown in a case series. ${ }^{21}$ The cytogenetic studies in our case were not typical for HL except $6 \mathrm{q}$ involvement and the clinical significance of these chromosomal findings and its disappearance in complete remission still remains to be elucidated.

In summary, we present an unusual case of HL with severe hepatic impairment, splenomegaly and multiple chromosomal abnormalities, which was treated successfully with gemcitabine and steroids to initially improve LFTs, such that six cycles of ABVD could be given. The patient remains in remission at 3.5 years after his initial diagnosis.

\section{Disclosure}

The authors report no conflicts of interest in this work.

\section{References}

1. Kuppers R. Clonotypic B cells in classic Hodgkin lymphoma. Blood. 2009;114(18):3970-3971.

2. Bonadonna G, Zucali R, Monfardini S, De Lena M, Uslenghi C. Combination chemotherapy of hodgkin's disease with adriamycin, bleomycin, vinblastine, and imidazole carboxamide versus MOPP. Cancer. 1975;36(1):252-259.

3. Canellos GP, Anderson JR, Propert KJ, et al. Chemotherapy of advanced Hodgkin's disease with MOPP, ABVD, or MOPP alternating with ABVD. N Engl J Med. 1992;327(21):1478-1484.

4. Leeuwenburgh I, Lugtenburg EP, van Buuren HR, Zondervan PE, de Man RA. Severe jaundice, due to vanishing bile duct syndrome, as presenting symptom of Hodgkin's lymphoma, fully reversible after chemotherapy. Eur J Gastroenterol Hepatol. 2008;20(2):145-147.

5. McCarthy J, Gopal AK. Successful use of full-dose dexamethasone, high-dose cytarabine, and cisplatin as part of initial therapy in nonhodgkin and Hodgkin lymphoma with severe hepatic dysfunction. Clin Lymphoma Myeloma. 2009;9(2):167-170.

6. Hong FS, Smith CL, Angus PW, Crowley P, Ho WK. Hodgkin lymphoma and fulminant hepatic failure. Leuk Lymphoma. 2010;51(5): 947-951.

7. Kaplan HS, Dorfman RF, Nelsen TS, Rosenberg SA. Staging laparotomy and splenectomy in Hodgkin's disease: Analysis of indications and patterns of involvement in 285 consecutive, unselected patients. Natl Cancer Inst Monogr. 1973;36:291-301.
8. Kaplan HS. Contiguity and progression in Hodgkin's disease. Cancer Res. 1971;31(11):1811-1813.

9. Bouroncle BA, Olf JW Jr, Vazques AG. Pathogenesis of jaundice in Hodgkin's disease. Arch Intern Med. 1962;110:872-883.

10. Birrer MJ, Young RC. Differential diagnosis of jaundice in lymphoma patients. Semin Liver Dis. 1987;7(3):269-277.

11. Bagley CM Jr, Thomas LB, Johnson RE, Chretien PB, DeVita VT Jr. Diagnosis of liver involvement by lymphoma: Results in 96 consecutive peritoneoscopies. Cancer. 1973;31(4):840-847.

12. Han WS, Jung ES, Kim YH, et al. 호지킨림프종에병발된간내담관 소멸증후군의자연관해[Spontaneous resolution of vanishing bile duct syndrome in hodgkin's lymphoma]. Korean J Hepatol. 2005;11(2): 164-168. Korean.

13. Cordoba Iturriagagoitia A, Inarrairaegui Bastarrica M, Perez de Equiza E, Zozaya Urmeneta JM, Martinez-Penuela JM, Beloqui Perez R. Recuperación ductular en el síndrome de los conductillos biliares evanescent en paciente con linfoma de Hodgkin [Ductal regeneration in vanishing bile duct syndrome in Hodgkin's lymphoma]. Gastroenterol Hepatol. 2005;28(5):275-278. Spanish.

14. Santoro A, Bredenfeld H, Devizzi L, et al. Gemcitabine in the treatment of refractory Hodgkin's disease: Results of a multicenter phase II study. J Clin Oncol. 2000;18(13):2615-2619.

15. Bartlett NL, Niedzwiecki D, Johnson JL, et al. Gemcitabine, vinorelbine, and pegylated liposomal doxorubicin (GVD), a salvage regimen in relapsed Hodgkin's lymphoma: CALGB 59804. Ann Oncol. 2007;18(6):1071-1079.

16. Baetz T, Belch A, Couban S, et al. Gemcitabine, dexamethasone and cisplatin is an active and non-toxic chemotherapy regimen in relapsed or refractory Hodgkin's disease: A phase II study by the national cancer institute of Canada clinical trials group. Ann Oncol. 2003;14(12): 1762-1767.

17. Gopal AK, Press OW, Shustov AR, et al. Efficacy and safety of gemcitabine, carboplatin, dexamethasone, and rituximab in patients with relapsed/refractory lymphoma: A prospective multi-center phase II study by the Puget Sound oncology consortium. Leuk Lymphoma. 2010; 51(8):1523-1529.

18. Czyz A, Romejko-Jarosinska J, Knopinska-Posluszny W, et al. Treatment strategy based on gemcitabine-containing salvage chemotherapy used with the intent to proceed to second stem cell transplantation for patients with Hodgkin lymphoma relapsing after a prior autologous transplant. Leuk Lymphoma. 2013;54(5):973-978.

19. Venook AP, Egorin MJ, Rosner GL, et al. Phase I and pharmacokinetic trial of gemcitabine in patients with hepatic or renal dysfunction: Cancer and leukemia group B 9565. J Clin Oncol. 2000;18(14):2780-2787.

20. Gemzar, Indianapolis, 1996 (Gemcitabine for injection) intravenous use. USA: Lilly USA LLC.

21. Ladanyi M, Parsa NZ, Offit K, Wachtel MS, Filippa DA, Jhanwar SC Clonal cytogenetic abnormalities in hodgkin's disease. Genes Chromosomes Cancer. 1991;3(4):294-299.

22. Barth TF, Martin-Subero JI, Joos S, et al. Gains of 2p involving the REL locus correlate with nuclear c-rel protein accumulation in neoplastic cells of classical hodgkin lymphoma. Blood. 2003;101(9):3681-3686.

23. Martin-Subero JI, Klapper W, Sotnikova A, et al. Chromosomal breakpoints affecting immunoglobulin loci are recurrent in Hodgkin and reed-sternberg cells of classical hodgkin lymphoma. Cancer Res. 2006;66(21):10332-10338.

Journal of Blood Medicine

\section{Publish your work in this journal}

The Journal of Blood Medicine is an international, peer-reviewed, open access, online journal publishing laboratory, experimental and clinical aspects of all topics pertaining to blood based medicine including but not limited to: Transfusion Medicine; Blood collection, Donor issues, Transmittable diseases, and Blood banking logistics; Immunohematology; Artificial and alternative

blood based therapeutics; Hematology; Biotechnology/nanotechnology of blood related medicine; Legal aspects of blood medicine; Historical perspectives. The manuscript management system is completely online and includes a very quick and fair peer-review system. Visit http://www.dovepress.com/ testimonials.php to read real quotes from published authors.

\section{Dovepress}

nal 